\title{
Enantioselective synthesis of tricyclic amino acid derivatives based on a rigid 4-azatricyclo[5.2.1.0 2,6]decane skeleton
}

\author{
Matthias Breuning ${ }^{* 1}$, Tobias Häuser $^{1}$, Christian Mehler ${ }^{1}$, \\ Christian Däschlein ${ }^{2}$, Carsten Strohmann ${ }^{2}$, Andreas Oechsner ${ }^{3}$ \\ and Holger Braunschweig ${ }^{3}$
}

\section{Full Research Paper}

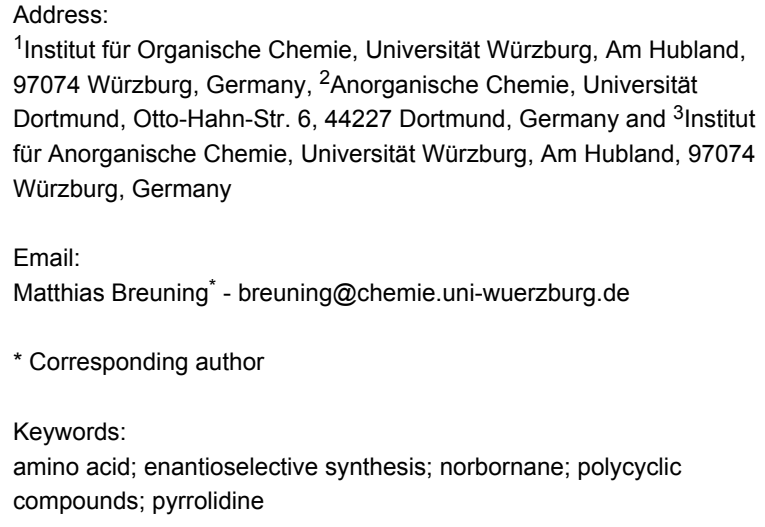

${ }^{1}$ Institut für Organische Chemie, Universität Würzburg, Am Hubland, 97074 Würzburg, Germany, ${ }^{2}$ Anorganische Chemie, Universität Dortmund, Otto-Hahn-Str. 6, 44227 Dortmund, Germany and ${ }^{3}$ Institut für Anorganische Chemie, Universität Würzburg, Am Hubland, 97074 Würzburg, Germany

Email:

Matthias Breuning ${ }^{*}$ - breuning@chemie.uni-wuerzburg.de

* Corresponding author

Keywords:

amino acid; enantioselective synthesis; norbornane; polycyclic compounds; pyrrolidine

Beilstein Journal of Organic Chemistry 2009, 5, No. 81. doi:10.3762/bjoc.5.81

Received: 20 August 2009

Accepted: 26 October 2009

Published: 21 December 2009

Associate Editor: N. Sewald

(C) 2009 Breuning et al; licensee Beilstein-Institut. License and terms: see end of document.

\begin{abstract}
An enantioselective route to four tricyclic amino acids and $N$-tosylamides, composed of a central norbornane framework with a 2-endo,3-endo-annelated pyrrolidine ring and a 5-endo- $\mathrm{C}_{1}$ or $-\mathrm{C}_{2}$ side chain, has been developed. A key intermediate was the chiral, $N$-Boc-protected ketone $(1 R, 2 S, 6 S, 7 R)$-4-azatricyclo[5.2.1. $\left.0^{2,6}\right]$ decan-8-one, available from inexpensive endo-carbic anhydride in five steps and $47 \%$ yield. The rigid scaffold makes these amino acid derivatives promising candidates for $\beta$-turn-inducing building blocks in peptidomimetics and for chiral auxiliaries in asymmetric organocatalysis.
\end{abstract}

\section{Introduction}

Unnatural amino acids with a rigid bowl-shaped backbone have received considerable interest in recent years. Incorporated in peptides or proteins, they may increase the metabolic stability and allow the introduction of novel structural motifs [1-4]. ß-Turns, for example, result if conformationally constrained spiro- or bicyclic amino acids such as $\mathbf{1}$ [5], 2 [6], and $\mathbf{3}$ [7,8] are embedded in peptidomimetics (Figure 1). Enantioselective organocatalysis [9-17] is another field of application for conformationally rigid amino acid derivatives. In this context, focus was also put on derivatives in which the activating acidic group is anchored at a more remote position of the molecule, but still in close spatial proximity to the amino function. Examples are $\beta$-proline (4) $[18,19]$, the bispidinium salt 5 [20], and the binaphthyl-derived amino acid 6 [21-23], which provided excellent enantioselectivities in several aldol and Mannich reactions. 


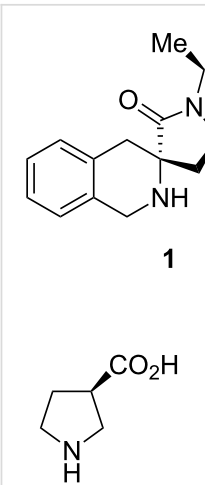

$\beta$-proline (4)

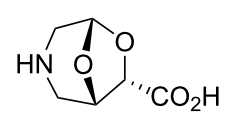

2

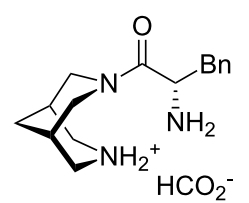

5<smiles>N[C@H]1C[C@@H]2CC[C@@H](C(=O)O)N2C1=O</smiles>

3

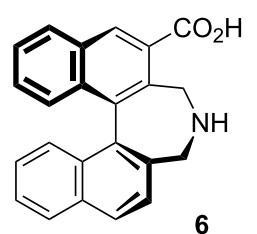

6
Figure 1: The conformationally rigid amino acid derivatives 1-3 ( $\beta$-turn-inducing building blocks) and 4-6 (successful organocatalysts).

Our studies targeted the chiral, tricyclic amino acid derivatives $\mathbf{7}$ and $\mathbf{8}$ (Figure 2), which possess a central norbornane framework equipped with a 2-endo,3-endo-annelated pyrrolidine ring. Due to the constrained, bowl-shaped backbone, these compounds may possess high potential as $\beta$-turn-inducing peptide building blocks and as bifunctional organocatalysts. In this paper we report on the first enantioselective synthesis of 7 and $\mathbf{8}$, which was achieved via the chiral ketone $\mathbf{9}$ as the key intermediate.
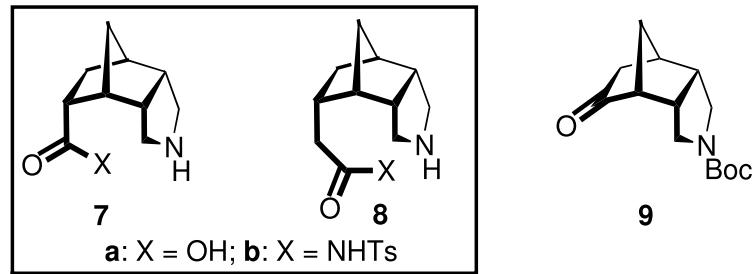

9

Figure 2: The targeted tricyclic amino acid derivatives 7 and 8 , and the key intermediate 9 .

\section{Results and Discussion}

The key intermediate, the tricyclic amino ketone 9, was first prepared in racemic form starting from inexpensive endo-carbic anhydride (10, Scheme 1). Conversion of the succinyl anhydride moiety in $\mathbf{1 0}$ into the pyrrolidine ring in $\mathbf{1 1}$ was accomplished in three steps and $74 \%$ yield by imide formation, reduction [24], and N-protection. Hydroboration/oxidation of the alkene function of $\mathbf{1 1}$ delivered the exo-configured alcohol $\mathrm{rac}$ 12, which was oxidized with PCC furnishing $\mathrm{rac}_{-} 9$ in $79 \%$ yield.

The asymmetric synthesis of the ketone 9 was realized by enantioselective hydration of the meso-alkene $\mathbf{1 1}$ using Hayashi's method (Scheme 2) [25-30]: Hydrosilylation with

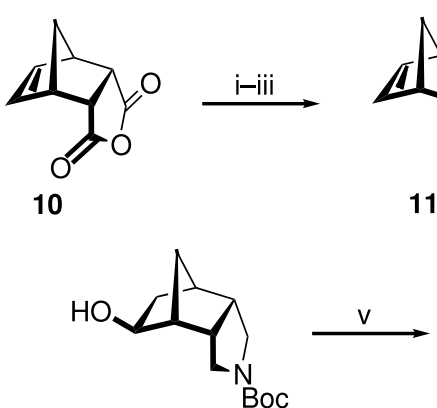

rac-12

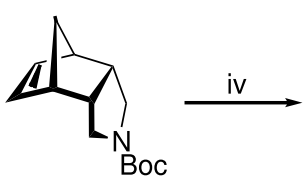

11
Scheme 1: Synthesis of the racemic ketone rac-9. i) $\mathrm{NH}_{4} \mathrm{OAc}, \mathrm{HOAc}$, $\Delta, 4$ d, $100 \%$; ii) $\mathrm{LiAlH}_{4}$, THF, $\Delta, 1$ d, $87 \%$ [24]; iii) $\mathrm{Boc}_{2} \mathrm{O}, \mathrm{CH}_{2} \mathrm{Cl}_{2}$, rt, 16 h, 85\%; iv) $\mathrm{NaBH}_{4}, \mathrm{Me}_{2} \mathrm{SO}_{4}$, THF, rt, 6 h, then $\mathrm{NaOH}, \mathrm{H}_{2} \mathrm{O}_{2}, \Delta, 90$ min, $75 \%$; v) PCC, Celite ${ }^{\circledR}, \mathrm{CH}_{2} \mathrm{Cl}_{2}$, rt, 16 h, $79 \%$.

trichlorosilane in the presence of a catalytic amount of $\left[\mathrm{Pd}\left(\mathrm{C}_{3} \mathrm{H}_{5}\right) \mathrm{Cl}\right]_{2}$ and $(R)$-MOP $[(R)$-2-diphenylphosphino-2'methoxy-1,1'-binaphthyl], followed by $\mathrm{SiCl}_{3} / \mathrm{OH}$ exchange, delivered the exo-alcohol 12 in $81 \%$ yield and $85 \%$ ee, as determined from the $(S)$ - and $(R)$-Mosher esters of $\mathbf{1 2}$. After oxidation (see Scheme 1), the chiral ketone 9 was thus available in overall five steps and $47 \%$ yield from 10 . The X-ray crystal structure of 9 is shown in Figure 3.

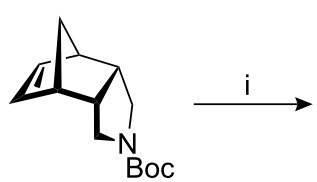

11

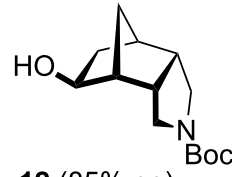

$12(85 \%$ ee $)$
Scheme 2: Enantioselective hydrosilylation/oxidation of 11. i) $\mathrm{HSiCl}_{3}$, $\left[\mathrm{Pd}\left(\mathrm{C}_{3} \mathrm{H}_{5}\right) \mathrm{Cl}_{2}(0.06 \mathrm{~mol} \%),(R)-\mathrm{MOP}(0.25 \mathrm{~mol} \%)\right.$, toluene, rt, $3 \mathrm{~d}$, then evaporate, then $\mathrm{KF}, \mathrm{KHCO}_{3}, \mathrm{H}_{2} \mathrm{O}_{2}$, THF/MeOH, rt, $1 \mathrm{~d}, 81 \%$.

Initial studies on the installation of the functionalized $\mathrm{C}_{1}$ side chain, as required for the amino acid derivatives 7 , were done on racemic material and aimed at an oxidation of the alkene rac-13 (Scheme 3), which was available from the ketone rac-9 either by Wittig reaction or by a Tebbe-type olefination [31] using $\mathrm{Mg}, \mathrm{TiCl}_{4}$, and $\mathrm{CH}_{2} \mathrm{Cl}_{2}$. Hydroboration/oxidation of rac13 occurred highly diastereoselectively on the exo-side providing the desired endo-alcohol rac-14, as determined by NOE measurements. Further oxidation with PCC gave the aldehyde $r a c-15$, albeit in low $13 \%$ overall yield from rac-9. As an alternative, the epoxidation of $r a c-\mathbf{1 3}$ with MCPBA was investigated, which delivered the spirocyclic exo-configured epoxide rac-16 in $46 \%$ overall yield from $r a c-9$ as the sole diastereomer. Lewis acid-catalyzed rearrangement of rac-16 with $\mathrm{BF}_{3}$ etherate [32] furnished the desired aldehyde rac-15 in $26 \%$ yield (12\% overall yield from rac-9) and the tetracyclic 


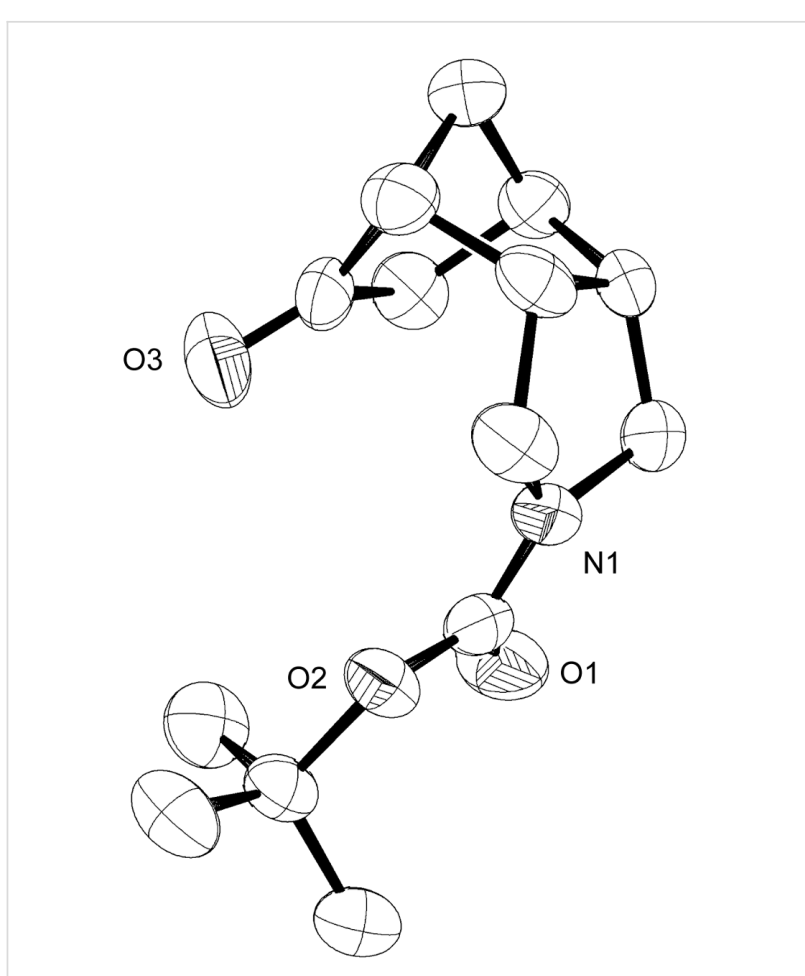

Figure 3: X-ray crystal structure of 9. X-ray data have been deposited with the Cambridge Crystallographic Data Centre (CCDC 743050).

$\mathrm{N}, \mathrm{O}$-acetal $\mathrm{rac}-\mathbf{1 7}$ in $35 \%$ yield. The latter compound is presumably formed from $\mathrm{rac}-\mathbf{1 5}$ by a Lewis acid-catalyzed, intramolecular, and thus proximity-facilitated tandem hydride transfer/cyclization sequence [33].

Since the yields of $\mathrm{rac}-\mathbf{1 5}$ from the alkene $\mathrm{rac}-\mathbf{1 3}$ were low, we turned our attention to an alternative approach via the enol ether 18, which was available from 9 as a 1:1 mixture of $E / Z$-isomers by Wittig reaction with $\mathrm{MeOCH}=\mathrm{PPh}_{3}$ (Scheme 4$)$. The selective hydrolysis of the enol ether moiety in $\mathbf{1 8}$ in the presence of the $N$-Boc-protective group was achieved by using trichloroacetic acid. The desired endo-configured aldehyde $\mathbf{1 5}$ was thus available in only two steps in good $64 \%$ overall yield from $\mathbf{9}$. After oxidation of $\mathbf{1 5}$ to the acid $\mathbf{1 9}$, the target amino acid $\mathbf{7} \cdot \mathbf{a} \cdot \mathrm{HCl}$ was obtained by $\mathrm{N}$-deprotection with aqueous $\mathrm{HCl}$ in overall four steps and $38 \%$ yield from 9 . The $N$-tosylamide $\mathbf{7 b} \cdot \mathrm{HCl}$ was accessed from $\mathbf{1 9}$ by condensation with $\mathrm{TsNH}_{2}$ under Steglich conditions followed by $\mathrm{N}$-deprotection with ethereal $\mathrm{HCl}$ (overall five steps and 12\% yield from 9).

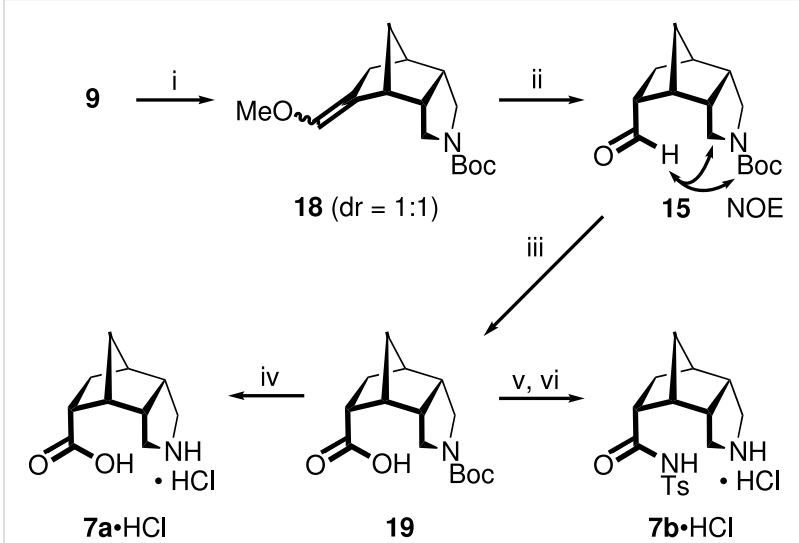

Scheme 4: Assembly of the amino acid $7 \mathrm{a} \cdot \mathrm{HCl}$ and the $\mathrm{N}$-tosylamide 7b· $\mathrm{HCl}$. i) $\mathrm{MeOCH}_{2} \mathrm{PPh}_{3}{ }^{+} \mathrm{Cl}^{-}, t$-BuOK, toluene/THF, rt, $1 \mathrm{~d}, 84 \%$; ii) $\mathrm{Cl}_{3} \mathrm{CCO}_{2} \mathrm{H}, \mathrm{H}_{2} \mathrm{O}, \mathrm{CH}_{2} \mathrm{Cl}_{2}$, rt, $1.5 \mathrm{~h}, 76 \%$; iii) $\mathrm{NaClO}_{2}, \mathrm{H}_{2} \mathrm{O}_{2}, \mathrm{KH}_{2} \mathrm{PO}_{4}$, $\mathrm{H}_{2} \mathrm{O} / \mathrm{MeCN}$, rt, 6 h, $75 \%$; iv) $\mathrm{HCl}, \mathrm{H}_{2} \mathrm{O}, \Delta, 1 \mathrm{~d}, 79 \%$; v) $\mathrm{TsNH}_{2}$, DCC, DMAP, $\mathrm{CH}_{2} \mathrm{Cl}_{2}$, rt, $1 \mathrm{~d}, 64 \%$; vi) $\mathrm{HCl}, \mathrm{Et}_{2} \mathrm{O}, \mathrm{MeOH}$, rt, $3 \mathrm{~h}, 38 \%$.

The preparation of the amino acid $\mathbf{8 a} \cdot \mathrm{HCl}$ and the $N$-tosylamide $\mathbf{8 b} \cdot \mathrm{HCl}$ required the attachment of an endo-oriented acetic acid substituent at the position of the keto group in $\mathbf{9}$ (Scheme 5). Initial attempts to introduce such a side chain by Wittig or Horner-Wadsworth-Emmons reactions, for example

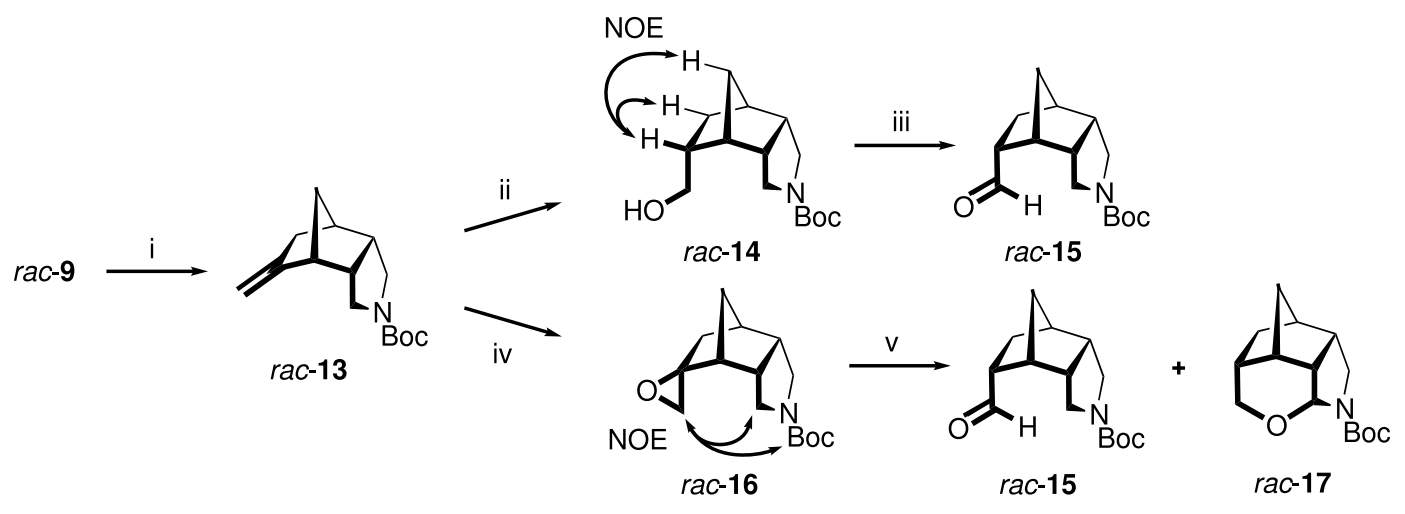

Scheme 3: Initial route to the aldehyde rac-15. i) $\mathrm{MePPh}_{3}{ }^{+} \mathrm{Br}^{-}, t-\mathrm{BuOK}$, toluene, $\Delta, 7 \mathrm{~h}, 77 \%$ or $\mathrm{Mg}, \mathrm{TiCl}_{4}, \mathrm{CH}_{2} \mathrm{Cl}_{2}, 0{ }^{\circ} \mathrm{C} \rightarrow \mathrm{rt}, 2 \mathrm{~h}, 55 \%$; ii) $\mathrm{NaBH}_{4}$, $\mathrm{Me}_{2} \mathrm{SO}_{4}, \mathrm{THF}, 0^{\circ} \mathrm{C} \rightarrow \mathrm{rt}, 18 \mathrm{~h}$, then $\mathrm{NaOH}, \mathrm{H}_{2} \mathrm{O}_{2}$, rt, $3 \mathrm{~h}, 34 \%$; iii) PCC, $\mathrm{CH}_{2} \mathrm{Cl}_{2}$, rt, $6 \mathrm{~h}, 51 \%$; iv) $\mathrm{MCPBA} \mathrm{CH}_{2} \mathrm{Cl}_{2}, \mathrm{rt}, 3 \mathrm{~h}, 60 \%$; v) $\mathrm{BF}_{3} \cdot \mathrm{OEt}_{2}$, toluene, $0{ }^{\circ} \mathrm{C}, 5 \mathrm{~min}, 35 \%(\mathrm{rac}-17)$ and $26 \%$ (rac-15). 
with $\mathrm{MeO}_{2} \mathrm{CCH}=\mathrm{PPh}_{3}$ or $\mathrm{MeO}_{2} \mathrm{CCH}_{2} \mathrm{P}(\mathrm{O})(\mathrm{OEt})_{2} / n$-BuLi, failed. By contrast, Peterson-type olefination using $\mathrm{TMSCH}_{2} \mathrm{CO}_{2} \mathrm{Et} / \mathrm{LDA}$ cleanly afforded the $\alpha, \beta$-unsaturated ester 20 as a 77:23 mixture of the $E / Z$-isomers in $50 \%$ yield. The reduction of the conjugated double bond with $\mathrm{Mg}$ in methanol furnished, after saponification, the endo-configured acid $\mathbf{2 1}$ as a single diastereomer. The further conversion of $\mathbf{2 1}$ into the target molecules was carried out in analogy to the preparation of $\mathbf{7 a} / \mathbf{b} \cdot \mathrm{HCl}$ from 19 (see Scheme 4), giving $\mathbf{8 a} \cdot \mathrm{HCl}$ in overall $24 \%$ yield from $\mathbf{9}$ (four steps) and $\mathbf{8 b} \cdot \mathrm{HCl}$ in overall $10 \%$ yield (five steps). The required endo-orientation of the acetic acid moiety in $\mathbf{8} \mathbf{a} \cdot \mathrm{HCl}$ was confirmed by the X-ray structure of the corresponding free base $\mathbf{8} \mathbf{a} \cdot \mathrm{MeOH}$ (Figure 4).

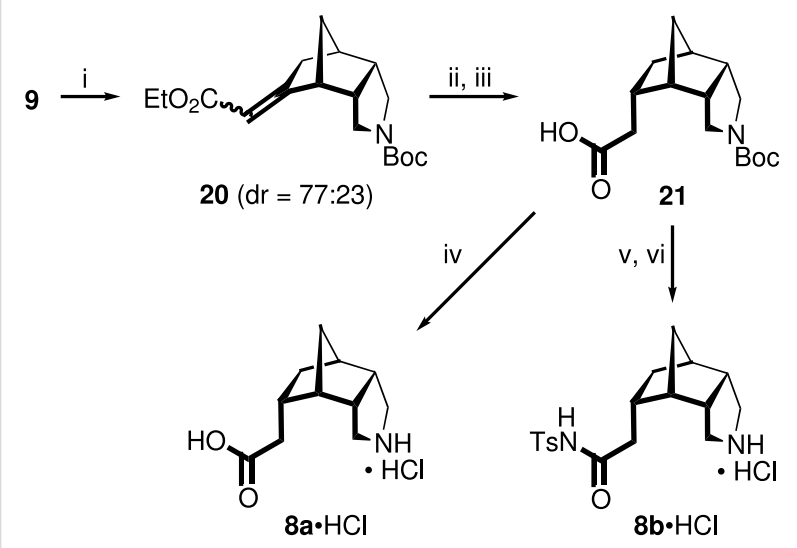

Scheme 5: Preparation of the amino acid $\mathbf{8 a} \cdot \mathrm{HCl}$ and the $\mathrm{N}$-tosylamide $8 \mathbf{b} \cdot \mathrm{HCl}$. i) $\mathrm{TMSCH}_{2} \mathrm{CO}_{2} \mathrm{Et}$, LDA, THF, $-78{ }^{\circ} \mathrm{C} \rightarrow \mathrm{rt}, 19 \mathrm{~h}, 50 \%$; ii) $\mathrm{Mg}, \mathrm{MeOH}, \mathrm{rt}, 16 \mathrm{~h}, 76 \%$; iii) $\mathrm{KOH}, \mathrm{EtOH} / \mathrm{H}_{2} \mathrm{O}, \Delta, 1 \mathrm{~d}, 90 \%$; iv) $\mathrm{HCl}$, $\mathrm{H}_{2} \mathrm{O}, \Delta, 1 \mathrm{~d}, 71 \%$; v) $\mathrm{TsNH}_{2}$, DCC, DMAP, $\mathrm{CH}_{2} \mathrm{Cl}_{2}, \mathrm{rt}, 4 \mathrm{~d}, 72 \%$; vi) $\mathrm{HCl}, \mathrm{Et}_{2} \mathrm{O}, \mathrm{rt}, 20 \mathrm{~h}, 42 \%$.

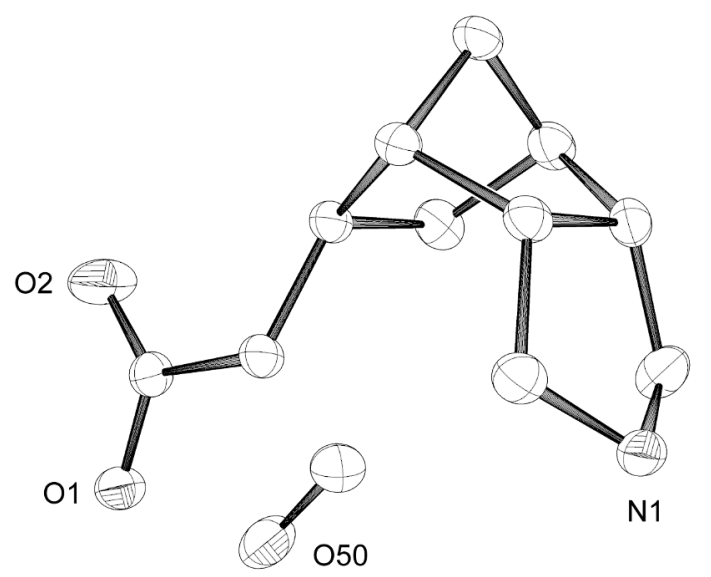

Figure 4: X-ray crystal structure of $8 \mathbf{a} \cdot \mathrm{MeOH}$. X-ray data have been deposited with the Cambridge Crystallographic Data Centre (CCDC 742656).
A first evaluation of the bowl-shaped amino acid derivatives 7 and $\mathbf{8}$ in standard organocatalytic aldol and Mannich reactions showed that these compounds are capable of promoting these reactions, albeit with low yields and enantioselectivities. Further investigations on this issue and on the use of $\mathbf{7}$ and $\mathbf{8}$ as $\beta$-turns are in progress.

\section{Conclusion}

The enantioselective syntheses of the bowl-shaped, tricyclic amino acids and $N$-tosylamides 7 and $\mathbf{8}$ were successfully accomplished in 9-10 steps starting with inexpensive endocarbic anhydride (10). The key stereochemical step was the desymmetrization of the meso-alkene 11 using Hayashi's hydrosilylation/oxidation procedure, which provided the endoalcohol 12 in $85 \%$ ee. The target molecules are promising candidates as $B$-turn-inducing building blocks in peptidomimetics and as chiral auxiliaries in organocatalysis.

\section{Supporting Information}

\section{Supporting Information File 1}

Full experimental details and characterization data for all new compounds.

[http://www.beilstein-journals.org/bjoc/content/ supplementary/1860-5397-5-81-S1.pdf]

\section{Supporting Information File 2}

NMR spectra of all new compounds.

[http://www.beilstein-journals.org/bjoc/content/ supplementary/1860-5397-5-81-S2.pdf]

\section{Supporting Information File 3}

Crystallographic data of the compounds $\mathbf{8 a} \cdot \mathrm{MeOH}$ and $\mathbf{9}$. [http://www.beilstein-journals.org/bjoc/content/ supplementary/1860-5397-5-81-S3.pdf]

\section{References}

1. Hill, D. J.; Mio, M. J.; Prince, R. B.; Hughes, T. S.; Moore, J. S. Chem. Rev. 2001, 101, 3893-4011. doi:10.1021/cr990120t

2. Komarov, I. V.; Grigorenko, A. O.; Turov, A. V.; Khilya, V. P. Russ. Chem. Rev. 2004, 73, 785-810. doi:10.1070/RC2004v073n08ABEH000912

3. Gardiner, J.; Abell, A. D. Org. Biomol. Chem. 2004, 2, 2365-2370. doi:10.1039/b406450j

4. Cativiela, C.; Díaz-de-Villegas, M. D. Tetrahedron: Asymmetry 2000, 11, 645-732. doi:10.1016/S0957-4166(99)00565-0

5. Lesma, G.; Landoni, N.; Pilati, T.; Sacchetti, A.; Silvani, A. J. Org. Chem. 2009, 74, 8098-8105. doi:10.1021/jo901480d

6. Danieli, E.; Trabocchi, A.; Menchi, G.; Guarna, A. Eur. J. Org. Chem. 2007, 1659-1668. doi:10.1002/ejoc.200600650

7. Dietrich, E.; Lubell, W. D. J. Org. Chem. 2003, 68, 6988-6996. doi:10.1021/jo034739d 
8. Ramana Rao, M. H. V.; Pinyol, E.; Lubell, W. D. J. Org. Chem. 2007, 72, 736-743. doi:10.1021/j00616761

9. Melchiorre, P.; Marigo, M.; Carlone, A.; Bartoli, G. Angew. Chem. 2008, 120, 6232-6265. doi:10.1002/ange.200705523

Angew. Chem., Int. Ed. 2008, 47, 6138-6171.

doi:10.1002/anie.200705523

10. Mukherjee, S.; Yang, J. W.; Hoffmann, S.; List, B. Chem. Rev. 2007, 107, 5471-5569. doi:10.1021/cr0684016

11. Tanaka, F.; Barbas, C. F., III. Aldol and Mannich-Type Reactions. In Enantioselective Organocatalysis; Dalko, P. I., Ed.; Wiley-VCH: Weinheim, Germany, 2007; pp 19-55.

12. Marigo, M.; Jørgensen, K. A. Chem. Commun. 2006, 2001-2011. doi:10.1039/b517090g

13. List, B. Chem. Commun. 2006, 819-824. doi:10.1039/b514296m

14. Notz, W.; Tanaka, F.; Barbas, C. F., III. Acc. Chem. Res. 2004, 37, 580-591. doi:10.1021/ar0300468

15. List, B. Tetrahedron 2002, 58, 5573-5590. doi:10.1016/S0040-4020(02)00516-1

16. Jarvo, E. R.; Miller, S. J. Tetrahedron 2002, 58, 2481-2495. doi:10.1016/S0040-4020(02)00122-9

17. List, B. Synlett 2001, 1675-1686. doi:10.1055/s-2001-18074

18. Zhang, H.; Mifsud, M.; Tanaka, F.; Barbas, C. F., III. J. Am. Chem. Soc. 2006, 128, 9630-9631. doi:10.1021/ja062950b

19. Zhang, H.; Mitsumori, S.; Utsumi, N.; Imai, M.; Garcia-Delgado, N.; Mifsud, M.; Albertshofer, K.; Cheong, P. H.-Y.; Houk, K. N.; Tanaka, F.; Barbas, C. F., III. J. Am. Chem. Soc. 2008, 130, 875-886. doi:10.1021/ja074907+

20. Liu, J.; Yang, Z.; Wang, Z.; Wang, F.; Chen, X.; Liu, X.; Feng, X.; Su, Z.; Hu, C. J. Am. Chem. Soc. 2008, 130, 5654-5655. doi:10.1021/ja800839w

21. Kano, T.; Takai, J.; Tokuda, O.; Maruoka, K. Angew. Chem. 2005, 117, 3115-3117. doi:10.1002/ange.200500408 Angew. Chem., Int. Ed. 2005, 44, 3055-3057. doi:10.1002/anie. 200500408

22. Kano, T.; Tokuda, O.; Takai, J.; Maruoka, K. Chem.-Asian J. 2006, 1 , 210-215. doi:10.1002/asia.200600077

23. Kano, T.; Maruoka, K. Chem. Commun. 2008, 5465-5473. doi:10.1039/b809301f

24. Michaelis, S.; Blechert, S. Chem.-Eur. J. 2007, 13, 2358-2368. doi: $10.1002 /$ chem. 200601183

25. Hayashi, T. Acc. Chem. Res. 2000, 33, 354-362. doi:10.1021/ar990080f

26. Hayashi, T. Catal. Today 2000, 62, 3-15. doi:10.1016/S0920-5861(00)00404-1

27. Hayashi, T. Catal. Surv. Jpn. 1999, 3, 127-135. doi:10.1023/A:1019075719151

28. Hayashi, T. Acta Chem. Scand. 1996, 50, 259-266. doi:10.3891/acta.chem.scand.50-0259

29. Hayashi, T.; Uozumi, Y. Pure Appl. Chem. 1992, 64, 1911-1916. doi:10.1351/pac199264121911

30. Uozumi, Y.; Lee, S.-Y.; Hayashi, T. Tetrahedron Lett. 1992, 33, 7185-7188. doi:10.1016/S0040-4039(00)60868-7

31. Yan, T.-H.; Tsai, C.-C.; Chien, C.-T.; Cho, C.-C.; Huang, P.-C. Org. Lett. 2004, 6, 4961-4963. doi:10.1021/ol0478887

32. Basabe, P.; Delgado, S.; Marcos, I. S.; Diez, D.; Diego, A.; De Román, M.; Urones, J. G. J. Org. Chem. 2005, 70, 9480-9485. doi:10.1021/jo0515529

33. Pastine, S. J.; Sames, D. Org. Lett. 2005, 7, 5429-5431. doi:10.1021/ol0522283

\section{License and Terms}

This is an Open Access article under the terms of the Creative Commons Attribution License

(http://creativecommons.org/licenses/by/2.0), which permits unrestricted use, distribution, and reproduction in any medium, provided the original work is properly cited.

The license is subject to the Beilstein Journal of Organic Chemistry terms and conditions:

(http://www.beilstein-journals.org/bjoc)

The definitive version of this article is the electronic one which can be found at: doi:10.3762/bjoc.5.81 